\title{
O ETHOS NARRATIVO EM BONS DIAS!, DE MACHADO DE ASSIS
}

\author{
Ivanete Bernardino Soares \\ Universidade Federal de Minas Gerais \\ Belo Horizonte (MG), Brasil
}

\begin{abstract}
Resumo: Neste artigo, buscaremos evidenciar alguns aspectos do método de composição de Machado de Assis, responsável pela elaboração de uma crítica sutil à sociedade de seu tempo. Para isso, analisaremos as técnicas discursivas utilizadas em uma série específica de crônicas, Bons dias!, publicada no final do século XIX no jornal Gazeta de Notícias do Rio de Janeiro. Dentre os recursos observados, destacaremos o processo de estilização de tipos sociais diversos por parte do narrador-cronista, capaz de gerar caricaturas sofisticadas da sociedade da época.
\end{abstract}

Palavras-chave: Machado de Assis; crônicas; estilo; crítica social.

\section{The narrative ethos in Bons dias!, by Machado de Assis}

\begin{abstract}
In this article, we seek to show some aspects of Machado de Assis's method of composition, which enabled him to subtly criticize the society of his time. In order to do so, we analyze the discourse techniques he used in a specific series of chronicles, Bons dias!, published at the end of the 19th century in the newspaper Gazeta de Notícias do Rio de Janeiro. Among the resources observed, we highlight the personification process of several social types the narrator-chronist creates, which is able to amount to sophisticated caricatures of the society at that time.
\end{abstract}

Keywords: Machado de Assis; chronicles; style; social criticism.

A sutileza e a complexidade formais características da estética machadiana driblaram por muito tempo a crítica voltada para sua obra. Muitos de seus estudiosos acusavam o escritor de assumir uma postura indiferente diante do seu contexto 
histórico, silenciando-se sobre as questões políticas, científicas e sociais de seu tempo. ${ }^{1}$ Hoje, já superado tal posicionamento, mais que identificar as matérias eleitas por sua sensibilidade crítica, resta-nos compreender, em profundidade, a técnica de composição discursiva que o possibilitou tecer um juízo crítico requintado e contundente diante do comportamento cambiante das classes sociais brasileiras, cuja identidade ainda mal se esboçava.

O estudo da crônica jornalística escrita por Machado de Assis contribuiu de maneira decisiva para a superação da ideia de alienação política e social já associada à produção machadiana. Antes mesmo de sua estreia romanesca, Machado exercitava seu espírito crítico nos moldes da crônica, registrando as contradições humanas e denunciando o comportamento desajustado das elites brasileiras. Ao longo da vida, Machado publicou mais de seiscentas crônicas, em diversos jornais de renome do Rio de Janeiro, alcançando a consagração no gênero muito antes de publicar seu primeiro romance, em 1872, o que levou alguns críticos a considerarem-no mais um cronistaescritor que um escritor-cronista. ${ }^{2}$

De maneira geral, as crônicas jornalísticas são modeladas, dentre outros condicionamentos, em função do perfil do periódico em que são publicadas, tendo em vista os possíveis interesses do público leitor. No caso da produção machadiana, podemos notar que cada uma das 12 séries de crônicas escritas ${ }^{3}$ apresenta uma combinação particular dos elementos narrativos comuns ao estilo machadiano, e uma forma discursiva mais ajustada com as questões que pretendia tratar. ${ }^{4}$ Apenas para ficarmos em um exemplo, enquanto a série História de quinze dias / História de trinta dias (Illustração Brasileira) se volta para questões de relevo cultural e científico,

\footnotetext{
${ }^{1}$ Um apanhado dessas posições se encontra em: MONTELLO, Josué. Os inimigos de Machado de Assis. Rio de Janeiro: Nova Fronteira, 1998.

${ }^{2}$ SOARES, Marcus Vinícius Nogueira. Machado de Assis: folhetim e crônica. In: ROCHA, João Cezar de Castro (Org.). À roda de Machado de Assis: ficção, crônica e crítica. Chapecó, SC: Argos, 2006. p. 365-394.

${ }^{3}$ Estamos considerando História de quinze dias (1876-1878) e História de trinta dias (1878) como pertencentes a uma mesma série, já que foram escritas no mesmo jornal, Illustração Brasileira, e tiveram o nome alterado apenas em função da mudança na periodicidade deste, antes distribuído quinzenalmente e, em seguida, mensalmente. Apesar dessa alteração de periodicidade, a estrutura composicional das crônicas e o estilo de sua linguagem permaneceram os mesmos.

${ }^{4}$ GLEDSON, John. Bons dias!. In:____ Por um novo Machado de Assis: ensaios. São Paulo: Companhia das Letras, 2006. p.135.
} 
utilizando-se de um estilo de linguagem sério e erudito, embora irônico, a série $A+B$ (Gazeta de Notícias) trata, prioritariamente, de atos políticos e questões econômicas, utilizando-se da forma do diálogo para compor seus textos e da criação de dois personagens para encená-lo - A e B.

Neste artigo, trataremos fundamentalmente da série Bons dias!, ${ }^{5}$ publicada no jornal Gazeta de Notícias do Rio de Janeiro entre 5 de abril de 1888 e 29 de agosto de 1889, perfazendo um total de 49 textos. O principal interesse é destacar algumas das estratégias discursivas e artísticas subjacentes à construção da imagem de seus narradores-cronistas. Acreditamos que o acionamento de perfis identitários diversos para a posição do narrador - algumas vezes em oposição clara - atende a uma demanda estética, já que parece mimetizar o comportamento de certos tipos sociais da época, colocando-os em situações burlescas, para melhor evidenciar seus vícios. Em razão da curta extensão do trabalho, nos concentraremos em exemplos extraídos de uma ou outra peça, a fim de justificar as afirmações apresentadas.

Em Bons dias!, como o próprio nome escolhido para a série indica, um dos recursos narrativos mais experimentados pelo escritor foi a conhecida conversa com o leitor. Mais do que um atrativo comercial para o periódico, essa característica de estilo atendia a uma antiga ambição de Machado de, por meio dos jornais, oferecer subsídios aos leitores para que pudessem fomentar o debate de ideias, participando democraticamente das tomadas de decisão públicas. Em alguns de seus primeiros artigos, publicados n'O Espelho, Machado pregava a "reforma pelo jornal", instrumento que poderia ampliar a participação popular nos trâmites políticos. Em artigo de 23 de outubro de 1859, por exemplo, ele afirma em tom engajado:

A primeira propriedade do jornal é a reprodução amiudada, e o derramamento fácil em todos os membros do corpo social. Assim, o operário que se retira ao lar, fatigado pelo labor cotidiano, vai lá encontrar ao lado do pão do corpo, aquele pão do espírito, hóstia social da comunhão pública. [...] Depois uma reflexão, depois um braço que se ergue, um palácio que se invade, um sistema que cai, um princípio que se levanta, uma reforma que se coroa. ${ }^{6}$

\footnotetext{
5 ASSIS, Machado de. Bons dias!. Introdução e notas: John Gledson. 3. ed. Campinas, SP: Editora da Unicamp, 2008.

${ }^{6}$ ASSIS, Machado de. A reforma pelo jornal. 23 de outubro de 1859. In: $O$ Espelho. Organização, introdução e notas de João Roberto Faria. Campinas, SP: Editora da Unicamp, 2009. p. 59-62.
} 
De alguma forma, essa perspectiva perpassa toda sua produção jornalística. No âmbito da enunciação, a composição da imagem do cronista parece estar sempre condicionada pela necessidade de estabelecimento de uma identificação com o leitor de jornais da época. Na maioria de suas crônicas, Machado se vale, como se disse, de uma técnica narrativa que consiste em dramatizar os tipos sociais mais influentes da época e não só - na figura do cronista, sem atritos diretos com as consciências leitoras, já que cada qual poderia ler o que melhor lhe conviesse ao espírito. Para alcançar esse efeito, articulou, a nosso ver, duas extremidades de um método de exposição que tem a vantagem de esconder os alicerces de sua estrutura: por um lado, torna a denúncia de seus vícios mais ostensiva e, por vezes, ambígua; por outro lado, personifica e promove a imagem do leitor por meio de uma caracterização particular de si mesmo, enquanto cronista. Machado instaura, assim, um dispositivo de crítica que, embora sem alarde, atinge as camadas mais subterrâneas da consciência e, em última instância, do funcionamento social, já que promove a autorreflexão do leitor por meio da identificação conturbada com o narrador de suas crônicas.

\section{O cronista de Bons dias!: um rapsodo moderno}

A instauração do narrador de Bons dias! se faz a partir de encenações variadas, nas quais o sujeito que narra ora se apresenta como um burguês decadente, ora como comerciante oportunista, ora como um sujeito apalermado, ora como um repórter inconveniente etc. Essa "volubilidade" do narrador machadiano, reconhecida por muitos críticos, foi caracterizada por Roberto $S_{c h w a r z}{ }^{7}$ como, mais do que uma técnica narrativa, um princípio formal estruturador em seus romances. A análise de Bons dias! nos leva a afirmar que também nas crônicas esse recurso foi muito utilizado. A forma assumida pelas crônicas da série, por exemplo, mistura uma grande variedade de gêneros discursivos no seu interior, mimetizando igualmente o estilo verbal e a dicção própria de cada um, o que implica, por sua vez, em uma reconstrução discursiva do ambiente social em que os seus modelos concretos teriam sido produzidos. Ao

\footnotetext{
7 SCHWARZ, Roberto. Um mestre na periferia do capitalismo: Machado de Assis. São Paulo: Duas Cidades, 1990.
} 
identificar um processo semelhante em Memórias póstumas de Brás Cubas, Schwarz considera que essa mistura acompanha a volubilidade do narrador no plano da forma: "[...] o movimento se completa no plano da forma, pela babel das modalidades literárias: trocam-se estilos, escolas, técnicas, gêneros, recursos gráficos, tudo comandado pelo mesmo afã de uma superioridade 'qualquer'". ${ }^{8}$

Para esse estudioso do romance machadiano, a volubilidade do narrador equivale à representação estética da ambivalência ideológica das elites brasileiras do final do Império. Em outras palavras, o caráter assumido pelo narrador funcionaria como um recurso mimético de representação da classe social dominante e se constituiria como a personificação de uma espécie de ética burguesa. Vale, neste caso, transcrever a interpretação de Schwarz a respeito desse fenômeno discursivo:

É uma espécie de desidentificação permanente, que leva, sucessivamente, ao abandono de todas as posições ideológicas importantes do tempo, não só brasileiras como, digamos, da cultura ocidental disponível para um brasileiro culto. Para exemplificar este processo: o narrador numa frase toma o acento bíblico, na frase seguinte o acento científico, na seguinte é um cronista mundano, depois é comerciante descarado e assim por diante. Temos então uma espécie de mascarada retórica, em que vão sendo percorridas as posições ideológicas do tempo [...], mas sem se identificar com nenhuma delas, pondo como resultado final a nulidade de todas. ${ }^{9}$

Esse tipo de abordagem da identidade do cronista machadiano é compatível com a abordagem discursiva da noção retórica de ethos $^{10}$ e valida sua aplicação também à instância narrativa, sem excluir, obviamente, a consideração pela natureza ficcional, assumida muitas vezes pelo discurso presente nas crônicas.

No início dos anos 1980, a noção de ethos foi retomada da tradição retórica pela perspectiva da análise do discurso, em função da centralidade dada por essa linha de pesquisa à questão do sujeito. A partir daí, a noção foi reconfigurada de acordo com seus pressupostos de ordem enunciativa e percebida como uma categoria pertinente para

\footnotetext{
${ }^{8}$ Idem, p. 30.

${ }^{9}$ SCHWARZ, Roberto. Mesa redonda. In: BOSI, Alfredo et al. Machado de Assis. São Paulo: Ática, 1982. p. 316.

${ }^{10}$ ARISTÓTELES. Retórica. São Paulo: Edipro, 2011.
} 
o entendimento das múltiplas facetas da socialização dos indivíduos. Assim, ethos pode ser definido como uma imagem do sujeito que enuncia, gerada pelo conteúdo e pelo estilo de seu discurso e, além disso, pelas condições de produção e de recepção desse último. Nesse sentido, o ethos é inseparável da situação comunicativa marcada historicamente, ou seja, cada conjuntura histórica se caracteriza por um regime específico de ethe, ${ }^{11}$ que são identidades ligadas a práticas discursivas e situações de comunicação que se tornam cristalizadas pela convenção social, aproximando-as da noção de estereótipo. Ao tratar da função do estereótipo na construção do ethos, Ruth Amossy afirma que uma das maneiras de legitimar a imagem de si que se quer construir é através de sua associação a representações que podem ser reconhecidas pelo interlocutor. Reitera ainda que "é preciso que sejam relacionadas a modelos culturais pregnantes, mesmo se se tratar de modelos contestatórios". ${ }^{12}$

Nas crônicas, os estereótipos sociais e psicológicos são representados alegoricamente pelos tipos. Dentre outras funções, esse recurso atende também a uma demanda de comicidade proposta pelo gênero que, por meio da figuração exagerada de alguns traços de comportamento, produzem uma caricatura facilmente identificável de um grupo social ou de uma orientação psicológica específica.

Ronaldes de Melo e Souza ${ }^{13}$ interpreta esse artifício narrativo como uma técnica própria da arte dramática e, inclusive, relaciona sua presença constante nos romances machadianos - e aqui, acrescentaríamos, também nas crônicas - à formação dramática de Machado de Assis. Como sabemos, os primeiros artigos jornalísticos publicados pelo escritor se ocupavam, quase exclusivamente, da crítica teatral. Soma-se a isso o conhecimento enciclopédico de Machado a respeito do drama clássico e moderno, além do fato de ter sido censor do Conservatório Dramático e escritor de peças teatrais. $^{14}$

\footnotetext{
${ }^{11}$ MAINGUENEAU, Dominique. A propósito do ethos. In: MOTTA, Ana Raquel; SALGADO, Luciana (Orgs.). Ethos discursivo. São Paulo: Contexto, 2008. p.19.

${ }^{12}$ AMOSSY, Ruth. O ethos na intersecção das disciplinas: retórica, pragmática, sociologia dos campos. In: ___ (Org.). Imagens de si no discurso: a construção do ethos. São Paulo: Contexto, 2005. p.125.

${ }^{13}$ SOUZA, Ronaldes de Melo e. O romance tragicômico de Machado de Assis. Rio de Janeiro: Eduerj, 2006. p. 31.

${ }^{14}$ FARIA, João Roberto (Org.). Machado de Assis: do teatro. Textos críticos e escritos diversos. São Paulo: Perspectiva, 2008. p. 21-102.
} 
Partidário do realismo artístico no âmbito do teatro, o Machado dos anos 1860 e 1870 defende a necessidade de uma função social da arte em contraposição à idealização romântica gratuita. Para ele, a arte deve imitar a vida, mas não como um retrato fiel em todas as suas formas, e sim a partir de um mecanismo próprio de reprodução de suas contradições, ${ }^{15}$ isto é, por meio de um regime mimético capaz de reconfigurar o real, nos moldes de uma outra lógica de funcionamento da forma. Nesse sentido, entendemos que o comportamento mímico-dramático do narrador que aparece nas crônicas de Bons dias! segue esse princípio estético apontado por Machado para o teatro, sendo-lhe atribuída a função de "copiar" a dicção particular de uma época e não apenas criar tipos idealizados, distantes da realidade social.

A metáfora teatral, frequentemente utilizada por analistas do discurso para explicar a encenação dos atos de linguagem, tem, neste caso, um emprego mais literal no desenvolvimento das proposições de Ronaldes de Melo e Souza. ${ }^{16}$ Este defende que o narrador machadiano desempenha o papel de um ator que se reveste de múltiplas máscaras, com o propósito de representar a dicção, fisionomia e comportamento (diríamos aqui, o ethos) de um outro sujeito, equiparando-o, assim, ao rapsodo da antiguidade clássica, ator que, por meio da alternância vocálica, desempenhava, sozinho, os mais variados papéis em uma única peça. Assimilada como recurso literário, a metamorfose narrativa representa potencialmente a pluralidade de vozes sociais, como confirma o crítico:

O narrador que finge múltiplas vozes ou que realiza a mimesis de várias atitudes constitui o exemplo extremo e sério da genuína representação da alteridade. Caracterizado como fingidor, cumpre a sublime função dramática de transmissor credenciado dos sentidos culturalmente consentidos pelos diversos estratos sociais da comunidade histórica. Não representa nenhuma ideologia em particular. ${ }^{17}$ Pelo contrário, representa a disputa das ideologias em luta. $^{18}$

\footnotetext{
${ }^{15}$ ASSIS, Machado. Ideias sobre o teatro. In: FARIA, João Roberto (Org.). Machado de Assis: do teatro. Textos críticos e escritos diversos. São Paulo: Perspectiva, 2008. p. 132.

${ }^{16}$ SOUZA, Ronaldes de Melo e. O romance tragicômico de Machado de Assis, cit., p.16-17.

${ }^{17}$ João Roberto Faria (2008) e Roberto Schwarz (1998) delimitam a concepção machadiana de classe em dois momentos distintos. Até a década de 1870, o escritor defenderia, em tom moralizante, uma ética burguesa da qual seria uma espécie de membro militante. A partir dessa época, Machado teria assumido uma visão desencantada dessa classe, conhecedor e consciente de seus vícios e consequente deterioração moral. Nesse caso, talvez pudéssemos falar em duas fases axiológicas que subjazem à sua obra, e não
} 
Neste ponto, podemos insistir na relação entre a função do rapsodo e a noção de ethos tal como reformulada por Maingueneau, para quem o ethos não corresponde necessariamente a um atributo real do sujeito empírico, mas a uma encenação discursiva que, por meio de uma maneira de dizer, implica uma maneira de ser. Ora, a maneira de dizer em um texto escrito equivale ao seu estilo, à especificidade da seleção do vocabulário, da organização sintática, da relação estabelecida com o leitor e das formas de heterogeneidade enunciativa, para ficarmos em alguns exemplos.

A partir dessas reflexões teóricas, tentaremos identificar, nas crônicas de Bons dias!, as maneiras de dizer do narrador que sinalizam uma maneira de ser, isto é, que revelam um ethos particular. A análise integral da série Bons dias! ${ }^{19}$ nos leva a afirmar que o ethos do narrador incorpora, em muitos momentos, uma maneira de ser egocêntrica e perversa, revelando, nos moldes da arte, os desvãos da natureza humana e a tensão entre a as inclinações íntimas do sujeito e suas necessidades de reconhecimento social.

\section{O narrador egocêntrico e o elitismo burguês}

No período imperial brasileiro, os títulos de nobreza e fidalguia eram concessões regidas por lei e, via de regra, eram outorgados àqueles que se sobressaíam pela riqueza, formação acadêmica, prestação de serviço militar ou pelo cargo público que ocupavam. ${ }^{20}$ Englobando todas essas atribuições, havia a prática do estabelecimento

fases necessariamente estéticas, como é mais comum. (FARIA, J. R. [Org.]. Machado de Assis: do teatro. Textos críticos e escritos diversos. São Paulo: Perspectiva, 2008; SCHWARZ, R. A novidade das Memórias póstumas de Brás Cubas. In: SECCHIN, A. C.; ALMEIDA, J.M.G. de, SOUZA, R. de M. e. Machado de Assis: uma revisão. Rio de Janeiro: In-Fólio. 1998. p.47-64). Na série Bons dias!, escrita no final dos anos 1880, já seria visível sua posição cética com relação aos valores burgueses, e a qualquer outro valor de classe, relativizando todos da mesma maneira, demonstrando, assim, o caráter ambivalente de todas as ideologias.

${ }^{18}$ SOUZA, Ronaldes de Melo e. O romance tragicômico de Machado de Assis, cit., p.16.

${ }^{19}$ Este trabalho corresponde a um segmento de uma pesquisa maior, que resultou na dissertação de mestrado intitulada A dimensão discursiva e estratégica das crônicas da série Bons dias!, de Machado de Assis, defendida em 2010, na Universidade Federal de Minas Gerais, sob a orientação do Prof. Dr. Renato de Mello.

${ }^{20}$ NEVES, Lúcia Maria Bastos Pereira das; MACHADO, Humberto Fernandes. O império do Brasil. Rio de Janeiro: Nova Fronteira, 1999. p. 269-275. 
de relações cordiais baseada na troca de favores e na manutenção das aparências, procedimento que tinha o poder, inclusive, de determinar uma imposição legal. A partir da Proclamação da República, a hierarquia nobiliária perdeu o valor de lei, permanecendo, no entanto, no imaginário social brasileiro, com base no qual a percepção de um indivíduo a partir de um status reconhecido é o que determina a forma de tratamento recebida nas diversas esferas da atividade social, daí a utilidade prática de se manter as aparências, encobrindo as eventuais deficiências pessoais no âmbito da moral, da boa convivência social e, até mesmo, na esfera econômica.

No fim do século XIX, período em que foram escritas as crônicas de Bons dias!, a conjuntura social da classe dominante "transformava seus membros em indivíduos com determinados privilégios e regalias, que os distinguiam do resto da sociedade". ${ }^{21}$ Seguindo essa cartilha, em diversas crônicas da série, o narrador apresenta um ethos egocêntrico, por meio de uma supervalorização de suas características pessoais, consideradas positivas; da autoafirmação de sua condição de nobreza e de sua distinção em relação ao resto da população, o que o leva a afirmar em uma das peças: "Vejam os leitores a diferença que há entre um homem de olho aberto, profundo, sagaz, próprio para remexer o mais íntimo das consciências (eu, em suma), e o resto da população". ${ }^{22}$

O esforço constante do narrador em se autopromover é coerente com a necessidade de legitimar seu ethos e assegurar seu pertencimento a um grupo restrito e elitista. Por outro lado, a recorrência de uma autoapresentação prepotente e arrogante do narrador das crônicas revela um uso estratégico da cenografia pelo enunciador, ${ }^{23}$ indiciando o propósito de exagerar a percepção do ridículo e provocar o sentimento de censura e reprovação por parte dos leitores, "educando-os" moralmente. Para John Gledson, um dos críticos machadianos mais dedicados ao entendimento desta série, esse perfil do narrador das crônicas apresenta similitudes significativas com os narradores

\footnotetext{
${ }^{21}$ Idem, p. 271.

${ }^{22}$ Crônica de 11 de maio de 1888 (ASSIS, Machado de. Bons dias!. Introdução e notas: Jonh Gledson, cit., p. 103).

${ }^{23}$ Em termos simples, o narrador corresponderia ao sujeito que assume diretamente o ato narrativo, enquanto o enunciador representaria o autor implícito. No caso das crônicas analisadas aqui, nota-se uma tensão constante entre uma e outra instância (FIORIN, J.L. A multiplicidade dos ethe: a questão da heteronímia. In: MOTTA, A. R.; SALGADO, L. (Orgs.). Ethos discursivo. São Paulo: Contexto, 2008. p. 55-69).
} 
dos romances, reforçando uma certa linha de continuidade estética entre romances, contos e crônicas. Sobre a sobreposição de significados em uma estrutura mais profunda nos textos machadianos, Gledson afirma:

[...] esses novos significados são frequentemente escondidos, ou cifrados, de um modo que se aproxima de uma agressão ao leitor. Se tenho razão, é isso que constitui a ligação mais profunda entre os romances e as crônicas. Veremos que situações em que a polidez e seu oposto potencial, a agressão, têm um papel crucial ocorrem continuamente em Bons dias!, logo depois do título. ${ }^{24}$

Além disso, a escolha desses recursos discursivos, caracterizadores de uma identidade hierarquicamente superior, pode ter sido condicionada também pela necessidade de reafirmação da imagem prévia que os cronistas brasileiros do século XIX possuíam. Nessa época, somente os escritores de mérito reconhecido eram convidados ao cargo de cronista dos maiores jornais, especialmente dos jornais cariocas. Assim, a fim de confirmar e justificar seus predicados diante dos leitores, o narrador se valia, muitas vezes, do conhecimento tácito desse ethos prévio, reforçando-o por meio do ethos dito. ${ }^{25}$ Já na crônica de abertura - datada de 5 de abril de 1888 e considerada como o projeto de escritura da série -, o narrador justifica o título da coluna por meio da apresentação de si como um sujeito polido e franco:

\section{Bons dias!}

Hão de reconhecer que sou bem criado. Podia entrar aqui, chapéu à banda, e ir logo dizendo o que me parecesse; depois ia-me embora, para voltar na outra semana. Mas, não senhor; chego à porta, e o meu primeiro cuidado é dar-lhe os bons dias. Agora, se o leitor não me disser a mesma coisa, em resposta, é porque é um grande malcriado, um grosseirão de borla e capelo; ficando, todavia, entendido que há leitor e leitor, e que eu, explicando-me com tão nobre franqueza, não me refiro ao leitor, que está agora com este papel na mão, mas ao seu vizinho. Ora bem! ${ }^{26}$

\footnotetext{
${ }^{24}$ GLEDSON, John. Bons dias!. In: Por um novo Machado de Assis: ensaios, cit., p. 138.

25 O ethos prévio seria a imagem do sujeito percebida pelo seu interlocutor antes mesmo de sua enunciação, isto é, construída por discursos anteriores ao ato enunciativo; já o ethos dito seria resultado da autorreferencialidade presente no discurso, neste caso, do próprio cronista, nos momentos em que ele faz afirmações sobre si mesmo. (MAINGUENEAU, D. A propósito do ethos. In: MOTTA, A. R.; SAlGADO, L. (Orgs.). Ethos discursivo. São Paulo: Contexto, 2008. p. 11-29).
}

${ }^{26}$ ASSIS, Machado de. Bons dias!. Introdução e notas: John Gledson, cit., p. 79. 
Fator de distinção e nobreza, a boa criação do narrador é reafirmada em diversas outras crônicas da série e corresponderia à dimensão do ethos dito, já que o narrador se vale do recurso da metalinguagem para se autocaracterizar, neste caso, positivamente. No entanto, em função da maneira de dizer utilizada, na maioria delas fica subentendida nas entrelinhas uma dimensão intencionalmente negativa desse papel encenado pelo narrador, expondo-se uma outra faceta de seu ethos. É o que se observa, por exemplo, em uma das últimas crônicas da série, de 3 de agosto de 1889. O mote inicial da crônica é um artigo publicado na véspera, que tratava das comemorações do $14^{\circ}$ aniversário do periódico Gazeta de Notícias. O texto trazia comentários sobre diversos articulistas do jornal, incluindo, neste grupo, o cronista de Bons dias!. Ao se referir ao "Boas noites", expressão com a qual Machado encerrava as crônicas da série, o autor do referido texto insinua que a vendagem do jornal aumentou muito devido às suas colaborações. O início da crônica de Machado é uma réplica ao artigo anterior e uma explicação mais precisa para o aumento de vendas, que atribui ao tratamento que ele mesmo dispensa aos seus leitores.

Nessa crônica, o narrador classifica seu comportamento bem educado como uma "utilidade prática", e isso logo após relacionar suas boas maneiras ao aumento de assinaturas e leitores do jornal: enquanto nenhum outro cronista do Gazeta demonstrava consideração explícita pelos seus leitores, saudando-os e mantendo com eles um diálogo constante, o jornal tinha pouca expressão de venda. A afirmação sugere que, ao contrário, a cordialidade do narrador de Bons dias! - a começar pelo nome da coluna seguido de exclamação, elemento de ênfase expressiva; e o constante recurso narrativo da conversa com o leitor - tinha a vantagem de aumentar as vendas e, em última instância, assegurar seu emprego de cronista. A boa criação é concebida aqui mais como estratégia de persuasão e adulação ("as pessoas bem criadas fazem mais atrativas as casas e reuniões"), cujo uso pode trazer algum tipo de lucro ("A Fortuna é mulher: gosta de ser cortejada."), do que uma consideração sincera pelo outro ("[...] como podem supor os frívolos"). ${ }^{27}$ É interessante ainda notar a revelação de alguns traços físicos do narrador no momento da enunciação - o que facilita, por parte do leitor, a percepção

${ }^{27}$ Idem, p. 281-283. 
corporificada da instância enunciativa, intensificando uma aproximação e identificação entre eles -, por meio de expressões como "gestos corteses", "de chapéu na mão", "distinto", "maneiras finas, polidas e graciosas", que complementam sua caracterização psicológica como "simples", "bom caráter" e "mansueto". No entanto, como foi dito, fica evidente o oportunismo do narrador quando insinua as vantagens materiais que tal comportamento pode trazer. Nesse caso, o ethos dito ou construído discursivamente pelo cronista não coincide inteiramente com o ethos mostrado por ele nas entrelinhas. Trata-se de uma narrativa a contrapelo, cuja revelação está vinculada aos indícios presentes na narrativa figurada na superfície textual.

Essa dubiedade de caráter do narrador - nódulo fundamental da crítica social subjacente à narrativa - aparece em outra crônica da série (1 de junho de 1888), na qual o ethos dito também corresponde à imagem de um sujeito de educação exemplar. Aproveitando-se da saudação-título da série como mote para o início da conversa, assim trava o contato com seu leitor: "Bons dias! Agora fale o senhor, que eu não tenho nada mais que lhe dizer. Já o saudei, graças à boa educação que Deus me deu, porque isto de criação, se a natureza não ajuda, é escusado trabalho humano". ${ }^{28}$ Além das características já apontadas nos fragmentos anteriores, nesta peça interessa especialmente a caracterização irônica que subjaz à construção do ethos desse cronista.

Em primeiro lugar, o narrador eleva uma característica sua à categoria de dom divino, o que o torna por si só especial em relação à maioria das pessoas, pois, nesse caso, a boa educação não é determinada apenas por um esforço de vontade ("Não estava em mim [...]"). Em seguida, o narrador menciona um episódio pessoal como prova de que seus bons modos o acompanham desde o berço, afirmando que chegava a pedir licença à ama para amamentar. A explicação que segue denota um efeito de sentido irônico: conta que, já nesta primeira fase da vida, refletia consigo mesmo a respeito da obrigação da ama de amamentá-lo, na condição de escrava alugada, e, consequentemente, concluía pela sua própria desobrigação de pedir licença a ela. Ora, é evidente o nonsense proposital dessa explicação, pois, no mínimo, é pouco verossímil o fato de uma criança em fase de amamentação desenvolver reflexões a respeito de um modo de trabalho como o escravismo, considerando direitos e obrigações.

${ }^{28}$ Idem, p.123. 
Demonstrando reconhecer (ironicamente) a inverossimilhança do exemplo dado, o narrador tenta atenuar o improvável da atitude de pedir licença à ama, por meio de mais essa explicação: "Pedia por gesto; parece que era um gesto de olhos [...]".

Nesse ponto, seu argumento se revela potencialmente como uma fraude, isto é, um ato ardiloso visando, nesse caso, impressionar. Nada garante que o "gesto de olhos" de uma criança que amamenta signifique uma reflexão grave e um pedido de permissão para mamar. Mas, se não se pode provar que assim pensava, também não se pode mostrar o contrário; esse é o raciocínio que parece sugerir. Tais escolhas discursivas e estilísticas funcionam, na fatura da crônica, como estratégias do enunciador, no sentido de revelar, implicitamente, a fragilidade do artifício de autovalorização do narrador. Esse recurso enunciativo é responsável pela manifestação de uma dimensão do ethos narrativo que não foi explicitamente anunciada pelo narrador, mas que a partir dele pode-se pressupor, embora pelo seu avesso.

Como última prova de que a boa criação o acompanha desde pequeno, referese a um episódio ocorrido nos primeiros anos escolares:

Aos cinco anos (era em 1831), como já sabia ler, davam-nos no colégio A Pátria, pouco antes fundada pelo Sr. Carlos Bernardino de Moura, com as mesmas doutrinas políticas que ainda hoje sustenta. A minha alma, que nunca se deu com política, dormia que era um gosto; mas os olhos não, esses iam por ali fora, risonhos, aprobatórios. ${ }^{29}$

Neste último trecho, especialmente, embora o ethos dito reafirme constantemente suas qualidades incomuns, o ethos efetivamente mostrado equivale a um comportamento pautado pelas aparências, envergado com o objetivo de manter uma relação favorável com o professor. Assim, enquanto seu espírito permanecia distante das discussões em pauta, novamente competiam aos olhos a demonstração de civilidade, uma vez que estes se mantinham "aprobatórios". Essa atitude de cordialidade, exposta de maneira caricata, remete ao mecanismo que regia as relações de hierarquia social no fim do século XIX, baseada na concessão de favores. De acordo com esse procedimento, a troca de adulações em público, as cortesias desmesuradas e demonstrações afetadas de enaltecimento alheio e próprio funcionavam como moeda

\footnotetext{
${ }^{29}$ Idem, p.123.
} 
corrente para a obtenção de vantagens, como uma distinção social, uma aliança política, o acesso a ambientes restritos e, inclusive, a mesas fartas, não se limitando a vantagens financeiras.

Em uma das crônicas, publicada em 11 de junho de 1888, em que refere a si mesmo como um ex-relojoeiro, o narrador admite que, enquanto exercia a profissão, costumava conceder o tratamento de "Excelência" a alguns fregueses mais carrancudos, com o fim de predispor-lhes o espírito para o consumo. Admite ainda que em muitos desses casos vendia o relógio por um preço superior ao marcado, ou seja, a bajulação do freguês rendia-lhe dividendos, não importando se alcançados por meios desonestos. Da mesma forma, mas de maneira inversa, conta que sempre recebeu igualmente o tratamento de "Excelência", mesmo que à custa de algum favor, que absolutamente não reconhece como suborno.

E fiquem sabendo que também eu recebia excelências, e agora receboas ainda mais; é certo, porém, que nunca me custaram dinheiro, porque eu não chamo dinheiro pagar o bonde a uma pessoa que me tratar bem, ou um sorvete, ou ainda um almoço. Isso paga-se até a pessoas mal-educadas. ${ }^{30}$

Em outra crônica ainda, em 3 de agosto de 1889, o narrador se vangloria da habilidade e utilidade do comportamento cortês e da fala macia para angariar vantagens calculadas: "Há por aí agora uma porção de conflitos públicos. [...] Pois eu seria capaz de os conciliar, tão somente com este meu ar cortês, que me faz entrar em todos os corações. [...] Entrar cortês e dizer macio - é a divisa de todo cidadão discreto." 31

Roberto Schwarz ressalta que, no Brasil, o modo de produção escravista funcionou como um dos determinantes para uma inversão dos valores burgueses, tal como estes se desenvolviam na Europa. A oposição ideológica entre o modo de produção brasileiro, baseado no trabalho forçado, e o liberalismo, que então se consolidava na Europa, seria uma das causas da dubiedade do comportamento ético das elites.

\footnotetext{
${ }^{30}$ Idem, p. 127.

${ }^{31}$ Idem, p. 282.
} 
O escravismo desmente as ideias liberais; mais insidiosamente o favor, tão incompatível com elas quanto o primeiro, as absorve e desfoca, originando um padrão particular. O elemento de arbítrio, o jogo fluido de estima e autoestima a que o favor submete o interesse material não podem ser integralmente racionalizados. [...] No processo de sua afirmação histórica, a civilização burguesa postulava a autonomia da pessoa, a universalidade da lei, a cultura desinteressada, a remuneração objetiva, a ética do trabalho etc. [...]. O favor, ponto por ponto, pratica a dependência da pessoa, a exceção à regra, a cultura interessada, a remuneração e serviços pessoais. ${ }^{32}$

Esse "jogo fluido de estima e autoestima" é internalizado e estilizado nas crônicas de Bons dias! por meio das estratégias utilizadas pelo narrador, que se autopromove a todo tempo e não esconde sua disposição para elogiar seus interlocutores oportunamente, inclusive o leitor. ${ }^{33}$ Uma estratégia comum de apresentação de seu ethos, por exemplo, consiste na comparação de si mesmo com uma personalidade de reconhecimento atestado, em alguns casos, personalidades bíblicas.

Voltando à crônica de abertura, ao explicar que não irá apresentar um programa para a nova série, equipara-se ao príncipe de Bismarck - que, como se sabe, foi autoritário e antidemocrata, tornando-se conhecido como o "Chanceler de Ferro" - e justifica sua diferença em relação a ninguém menos que Deus, já que este último instituiu um programa por meio do ato de criação do homem.

Deus fez programa, é verdade (E Deus disse: Façamos o homem à nossa imagem e semelhança, para que presida etc. Gênese, I, 26); mas é preciso ler esse programa com muita cautela. Rigorosamente, era um modo de persuadir ao homem a alta linhagem de seu nariz. Sem aquele texto, nunca o homem atribuiria ao Criador, nem a sua gaforinha, nem a sua fraude. ${ }^{34}$

A necessidade de promover sua imagem fica evidente em outras passagens, como no fragmento da crônica de 1 de junho de 1888 em que relata o desgosto de

\footnotetext{
${ }^{32}$ SCHWARZ, Roberto. Ao vencedor as batatas: forma literária e processo social nos inícios do romance brasileiro. 3. ed. São Paulo: Duas Cidades, 1988. p.16.

${ }^{33}$ De maneira geral, a relação estabelecida pelo narrador de Bons dias! com o leitor é ambígua, ora tratando-o com deferência afetada, ora o afrontando e até mesmo ofendendo.
}

${ }^{34}$ ASSIS, Machado de. Bons dias!. Introdução e notas: John Gledson, cit., p.80. 
alguns amigos por não verem seus nomes estampados nos festejos da Abolição da Escravatura, que havia acontecido no mês anterior. O narrador destaca suas qualidades intelectuais comparando-se com o filósofo ateniense Sócrates, justificando-se, em seguida, por meio da descrição de seu ato:

\begin{abstract}
Aqui é que eu quisera ser um homem malcriado. $\mathrm{O}$ menos que diria a todos é que eles tanto trabalharam para a abolição dos escravos, como para a destruição de Nínive, ou para a morte de Sócrates... Eu, com uma sabedoria só comparável à deste filósofo, respondi que a História era um livro aberto, e a justiça, a perpétua vigilante. Um dos convivas, dado a frases, gostou da última, pediu outra e um cálice de Alicante. Respondi, servindo o vinho, que as reparações póstumas eram mais certas que a vida, e mais indestrutíveis que a morte. Da primeira vez fui vulgar, da segunda creio que obscuro; de ambas sublime e bem criado. $^{35}$
\end{abstract}

Essa transcrição tem a vantagem de reproduzir a dicção do narrador, expressiva de uma dimensão implícita de seu ethos. Em primeiro lugar, ele expõe a contradição entre aquilo que pensou diante dos amigos - isto é, que eles não tiveram seus nomes divulgados e alardeados, porque não contribuíram em absolutamente nada para o desfecho da Abolição - e aquilo que ele realmente proferiu para consolá-los: "[...] a História era um livro aberto, e a justiça, a perpétua vigilante". Aqui, o uso de frases desgastadas, com aparência de clichês, não parece remeter à sabedoria de Sócrates, fato que o próprio enunciador denuncia ao atribuir ao narrador a expressão "um dos convivas, dado a frases [...]", que denota a frivolidade do dito. Apesar disso, o narrador, envaidecido pelo elogio, continua com outras frases de igual valor: "[...] as reparações póstumas [são] mais certas que a vida, e mais indestrutíveis que a morte". Admite, por fim, que seus ditos foram vulgares e obscuros, mas, certamente sublimes, porque figuraram como uma demonstração de boa criação e cortesia.

Nos dois fragmentos que seguem, o narrador se equipara a dois personagens bíblicos, o apóstolo Paulo e Salomão, destacando sua superioridade com relação a ambos:

\footnotetext{
${ }^{35}$ Idem, p. 124.
} 
Não gosto de fazer grandes comparações comigo; lá vai uma, e é a última. Achei-me na estrada de Damasco, tal qual São Paulo, e ouvi, à semelhança daquele divino apóstolo, estas palavras, iguais às do Senhor: "Por que me persegue?" A diferença é que São Paulo tamanho foi o seu deslumbramento - perdeu a vista, não podendo mais que ouvir a voz misteriosa. Eu, ao contrário, vi tudo [...]. ${ }^{36}$

[...] se os contendores me confiassem a decisão do negócio, achariam o melhor dos Salomões, porque não consta da Escritura (posto não conste o contrário) que Salomão fosse tão primoroso e delicado como eu. Bárbaro era, ordenando a divisão do filho; eu, no caso dele, insinuaria a aliança das mães. ${ }^{37}$

No primeiro, o narrador nega o hábito de "fazer grandes comparações" consigo mesmo, mas, no entanto, o faz, neste e no fragmento seguinte, pertencente a uma crônica posterior. Ao mesmo tempo em que aponta semelhanças notáveis entre si e o apóstolo, já que ambos ouviram uma voz divina, ressalta que o segundo não pôde ver o Senhor, porque perdera a visão, enquanto ele, sem o "deslumbramento" prejudicial, pôde compreender tudo o que desejava, sugerindo dessa forma uma orientação interpretativa de que foi ainda superior a São Paulo. No segundo fragmento, utiliza-se de um argumento estrategicamente inconsistente para provar que é mais "primoroso" e "delicado" do que o sábio rei Salomão. Se não consta na Escritura que ele, narrador, tem em menos conta tais características, logo, ele pode afirmar que as têm em maior medida. Mantendo esse sentido, poderíamos associar tal posicionamento, aliás muito recorrente nas crônicas de Machado, a uma máxima do direito administrativo a partir da qual, para o cidadão comum, tudo aquilo que não está na lei é permitido; uma analogia possível com as regalias de classe permitidas por lei, à época. Era o que pensava padre Miguel do Sacramento Lopes da Gama, fundador e único redator do jornal pernambucano $O$ Carapuceiro (1832-47), que assim expressava sua reprovação frente à presunção de superioridade, a que chama "fofice", da classe social de maior status:

Eu da aristocracia só reprovo a fofice, só reprovo que o indivíduo, porque é ou se diz nobre, queira estribar nisto o seu mérito, queira só ele dirigir os negócios da pátria, e trate o resto dos homens com desprezo, sobranceria e crimeza. E ainda mais enoja tal filáucia,

\footnotetext{
${ }^{36}$ Idem, p. 240.

${ }^{37}$ Idem, p. 282.
} 
quando esse título de nobreza é tão duvidoso como a existência dos habitantes da Lua, e não passa de mera presunção e fofice. ${ }^{38}$

Para Schwarz, as ideias burguesas - que teoricamente remetem aos ganhos auferidos com o processo da Ilustração -, no Brasil pré-republicano, "tomam função de... ornato e marca de fidalguia: atestam e festejam a participação numa esfera augusta [...]". ${ }^{39}$ Entendemos que, acompanhando essa forma social por meio de uma construção consciente do ethos do narrador, o enunciador das crônicas de Bons dias! internalizou esteticamente essa característica da sociedade brasileira, ao mesmo tempo em que, por meio de estratégias discursivas específicas, como a caricaturização de certos traços de seu caráter, desenvolveu implicitamente uma crítica social contundente e sarcástica, embora não o fizesse em proveito de nenhuma ideologia em particular.

Ao contrário do diagnóstico inicial de alguns críticos a respeito de uma suposta ausência de comprometimento com as questões da época, a análise do método de composição das obras de Machado de Assis, especialmente de suas crônicas, revela não apenas o inverso, mas evidencia um olhar arguto e uma amplitude de avaliação raros na literatura brasileira dos Oitocentos.

Referências:

AMOSSY, Ruth. O ethos na intersecção das disciplinas: retórica, pragmática, sociologia dos campos. In:

Paulo: Contexto, 2005. . (Org.). Imagens de si no discurso: a construção do ethos. São

ARISTÓTELES. Retórica. São Paulo: Edipro, 2011.

38 LOPES GAMA, O Carapuceiro, 1839. Citado por: NEVES, Lúcia Maria Bastos Pereira das; MACHADO, Humberto Fernandes. O império do Brasil. Rio de Janeiro: Nova Fronteira, 1999. p. 269.

${ }^{39}$ SCHWARZ, Roberto. Ao vencedor as batatas, cit., p.18. 
ASSIS, Machado. Ideias sobre o teatro. In: FARIA, João Roberto (Org.). Machado de Assis: do teatro. Textos críticos e escritos diversos. São Paulo: Perspectiva, 2008. p. 132.

Bons dias!. Introdução e notas: John Gledson. 3. ed. Campinas, SP: Editora da Unicamp, 2008.

A reforma pelo jornal. 23 de outubro de 1859. In: O Espelho. Organização, introdução e notas de João Roberto Faria. Campinas, SP: Editora da Unicamp, 2009. p. 59-62.

FARIA, João Roberto (Org.). Machado de Assis: do teatro. Textos críticos e escritos diversos. São Paulo: Perspectiva, 2008.

FIORIN, J.L. A multiplicidade dos ethe: a questão da heteronímia. In: MOTTA, A. R.; SALGADO, L. (Orgs.). Ethos discursivo. São Paulo: Contexto, 2008. p. 55-69.

GLEDSON, John. Bons dias!. In: Por um novo Machado de Assis: ensaios. São Paulo: Companhia das Letras, 2006.

MAINGUENEAU, Dominique. A propósito do ethos. In: MOTTA, Ana Raquel; SALGADO, Luciana (Orgs.). Ethos discursivo. São Paulo: Contexto, 2008.

MONTELlO, Josué. Os inimigos de Machado de Assis. Rio de Janeiro: Nova Fronteira, 1998.

NEVES, Lúcia Maria Bastos Pereira das; MACHADO, Humberto Fernandes. $O$ império do Brasil. Rio de Janeiro: Nova Fronteira, 1999.

SCHWARZ, Roberto. Mesa redonda. In: BOSI, Alfredo et al. Machado de Assis. São Paulo: Ática, 1982.

Ao vencedor as batatas: forma literária e processo social nos inícios do romance brasileiro. 3. ed. São Paulo: Duas Cidades, 1988.

Cidades, 1990.

Um mestre na periferia do capitalismo: Machado de Assis. São Paulo: Duas

A novidade das Memórias póstumas de Brás Cubas. In: SECCHIN, A. C.; ALMEIDA, J.M.G. de, SOUZA, R. de M. e. Machado de Assis: uma revisão. Rio de Janeiro: In-Fólio. 1998. p.47-64.

SOARES, Marcus Vinícius Nogueira. Machado de Assis: folhetim e crônica. In: ROCHA, João Cezar de Castro (Org.). À roda de Machado de Assis: ficção, crônica e crítica. Chapecó, SC: Argos, 2006. p. 365-394.

SOUZA, Ronaldes de Melo e. O romance tragicômico de Machado de Assis. Rio de Janeiro: Eduerj, 2006.

Ivanete Bernardino Soares é doutoranda em Letras na Universidade Federal de Minas Gerais. É autora, entre outros, de A transitoriedade estilística na crônica de Machado 
de Assis, sobre a variação de estilos na prosa jornalística machadiana, e A política de ontem e de hoje na crônica de Machado de Assis, sobre as estratégias de construção da imagem do agente político do século XIX, muito próxima daquela estereotipada na contemporaneidade. Atualmente, conclui pesquisa de doutorado a respeito de duas séries de crônicas machadianas: Notas semanais e Bons dias!. E-mail: <ivanete1@yahoo.com.br>

Recebido: $15 / 08 / 2012$

Aprovado: 29/10/2012 